\title{
Giant subcutaneous Angiofibrolipoma: successful surgical approach in a Bulgarian patient
}

\author{
Georgi Tchernev $^{1 凶}$, Anastasiya Atanasova Chokoeva² James W. Patterson $^{3}$
}

Received: 5 April 2016 | Returned for modification: 6 May 2016 | Accepted: 10 May 2016

\section{To the Editor:}

We report on a 37-year-old male patient that presented to our dermatological polyclinic with complains of moderate pain and discomfort provoked by a tumor-like formation on the left shoulder blade region. The lesion had begun $3^{1 / 2}$ years prior to his clinic visit. Clinical examination revealed a large subcutaneous tumor with a soft consistency and sharply demarcated borders located on the patient's back and covering almost the entire left scapula. The mass appeared to be encapsulated and moderately mobile, and it lacked clinical evidence of infiltration of the surrounding
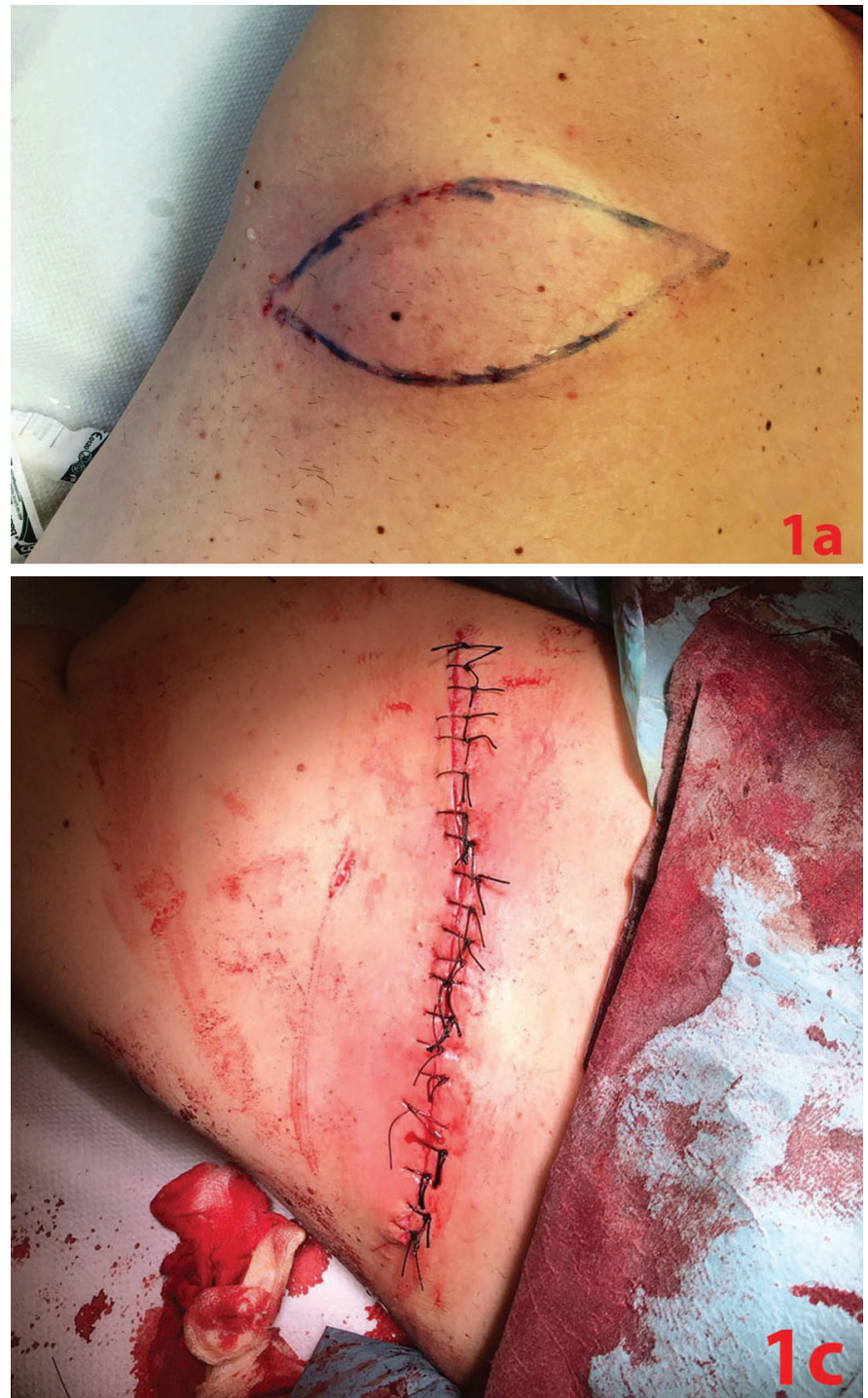

tissues. There was a moderate degree of pain on palpation. Clinically, it resembled a large lipoma (Fig. 1a). Laboratory blood tests and diagnostic imaging procedures, including abdominal/cutaneous ultrasonography and chest X-ray, failed to reveal any other significant abnormalities. After testing to ensure a negative allergic reaction to local anesthetic agents, we performed a total surgical excision of the formation and closed the wound with multiple single stiches (Figs. 1b, c).

Histopathologic findings included a fibrous capsule, numerous
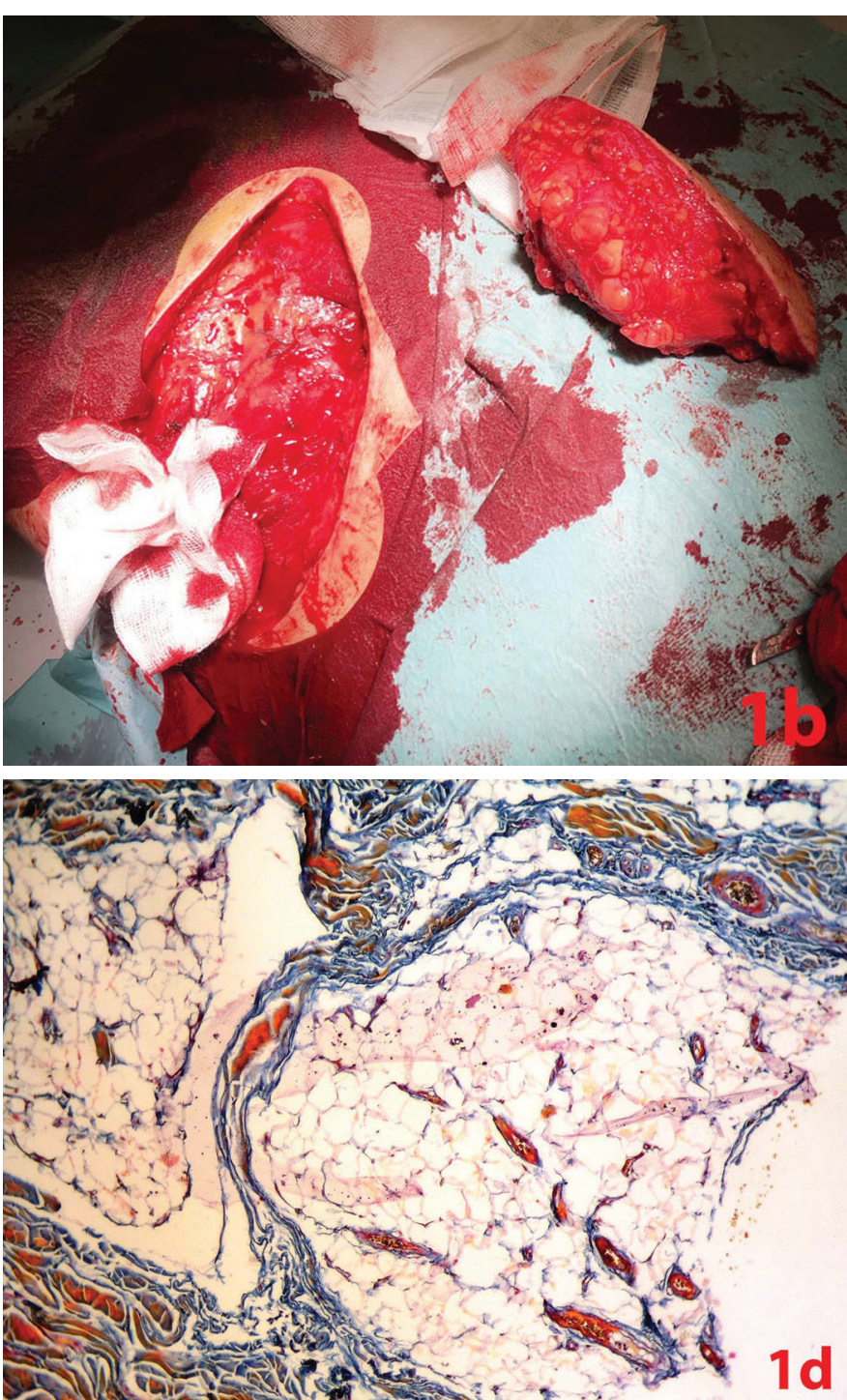

Figure 1 | a. Clinical manifestation of the giant subcutaneous angiofibrolipoma, with pre-operative marking of the surgical borders, located on the left scapula of a 37 -year-old male patient. $\mathbf{b}$. Intraoperative view of the excised tumor formation, involving part of the $\mathrm{m}$. trapezius major, with a partial resection of the muscle. c. Postoperative clinical manifestation immediately after the procedure. The surgical defect was sutured layer by layer with application of subcutaneous absorbable sutures to achieve optimal low voltage on the following dermal stitches. d. Histopathological findings established the presence of mature adipocytes, blood vessels, and dense collagenous tissue.

${ }^{1}$ Department of Dermatology, Venereology and Dermatologic Surgery, Medical Institute of MVR-Sofia, Ministry of the Interior, Sofia, Bulgaria. ${ }^{2}$ Onkoderma - Polyclinic for Dermatology and Dermatologic Surgery, Sofia, Bulgaria. 3Department of Pathology, University of Virginia Health System, Charlottesville, VA, USA. $\bowtie$ Corresponding author: georgi_tchernev@yahoo.de 
thin-walled vessels engorged with erythrocytes, nests of lipocytes (Fig. 1d), and prominent strands of fibrous connective tissue. The histopathological findings verified the diagnosis of subcutaneous angiofibrolipoma.

Angiofibrolipoma has been described as one of the rarest histopathological variants of lipoma, with occurrence most often in thehead and neck region $(1,2)$. Clinically, it is similar to conventional lipoma because it usually presents as a solitary, subcutaneous, well-circumscribed lesion (3). Lipomas are typically composed of mature adipocytes and arise from subcutaneous tissues of the trunk, neck, and proximal extremities. However, there are also numerous histopathologic variants, including spindle cell, atypical or pleomorphic, sclerotic, glandular, fibrohistiocytic, and chondroid lipomas (4), myxolipomas (5), fibrolipomas, angiolipomas, angiomyolipomas, and infiltrating angiolipomas; these are categorized according to their content of fat, muscle, blood

\section{References}

1. Çetin MA, İkincioğulları A, Göktürk UG, Baran H, Ensari S, Hatipoğlu HG, et al. Intranasal angiofibrolipoma. Kulak Burun Bogaz Ihtis Derg. 2013;23:291-4. doi: 10.5606/kbbihtisas.2013.04695.

2. Bochnia M, Grabowski K, Zalewska A, Morawska-Kochman M. Angiofibrolipoma of the larynx: Case report and literature review. Head Neck. 2016;38:E81-E83.

3. Liu QL, Tian B, Zhang H, Qiao DS. Angiofibrolipoma of the spermatic cord. Asian J Androl. 2009;11:746-7.

4. Patterson JW. Practical skin pathology. Philadelphia (USA): Elsevier; c2013. Wick MR, Patterson JW: Tumors and tumor-like conditions showing neural, nerve sheath, and adipocytic differentiation. p. 560.

5. Weiss SW, Goldblum JR. Soft tissue tumors. St. Louis (USA): Mosby; c2001. Benign lipomatous tumors. p. 578.

6. Pérez-Navarro JV1, Flores-Cardoza A, Anaya-Prado R, González-Izquierdo Jde J, Ramírez-Barba EJ. Angiofibrolipoma of the greater omentum: case report and literature review. Cir Cir. 2009;77:229-32. Spanish. vessel, connective tissue, or other structures (3). In contrast to an angiomyolipoma, which is composed of blood vessels, smooth muscle cells, and adipocytes, an angiofibrolipoma shows a different combination of elements; namely, a combination of mature adipocytes and blood vessels with dense collagenous tissue (as in our case) (3). Angiofibrolipomas have most often been reported in non-cutaneous locations, including the intranasal cavity (1), larynx (2), spermatic cord (3), greater omentum (6), pericardium (7), tonsils (8), and kidney (9). Only two reports appear to describe this lesion in subcutaneous tissues: one in the calf (10) and another in the foot (11). To the best of our knowledge, this is the first reported case of a giant subcutaneous angiofibrolipoma located on the back of an adult patient.

Total surgical excision and a 5-year postoperative follow-up are recommended in order to assess the possibility of recurrence or malignancy (2).
7. Hojman D. Mixed tumor of the pericardium: angiofibrolipoma. Prensa Med Argent. 1949;36:2478-81.

8. Krausen C, Becker K, Hamann KF. Angiofibrolipoma of the tonsil. Laryngol Rhinol Otol (Stuttg). 1986;65:355-6.

9. Tóth C. Kidney angiofibrolipoma. Z Urol Nephrol. 1975;68:279-82.

10. Uwale Eyesan S, Christopher Ayeni S, Adesope Adesina S, Tolulope Kehinde G, Olawepo A, Kazeem Ibrahim 0. Angiofibrolipoma of the calf. Rare Tumors. 2013;5:e48.

11. Kershisnik W, McCarthy DJ, O’Donnell E. Angiofibrolipoma. A histologic variant of the lipoma. J Am Podiatr Med Assoc. 1986;76:67-70. 